【論 文】

\title{
農村における幸福度の評価と分析
}

\author{
廣政幸生・長尾真弓・中嶋晋作 \\ (明治大学農学部)
}

\section{An Analysis on Evaluation of Happiness in Rural Area}

\author{
Yukio HIROMASA(Meiji University) \\ Mayumi NAGAO(Meiji University) \\ Shinsaku NAKAJIMA(Meiji University)
}

A degree of happiness may be measured as an index of QOL although depending on subjective judgment. Most economists discuss it from macro-economic view point but few have examined it at regional or rural area levels. This paper aims at clarifying to what extent rural residents feel happiness and for what reasons. A questionnaire survey was conducted for 53 farm households and 70 non-farm households in Yuza town of Yamagata prefecture. Happiness was questioned on four items: an overall happiness, pleasure of life, sense of achievement in life and life satisfaction. 16 questions were asked regarding life satisfaction and in addition to 3 items for

\section{1.はじめに}

我が国においてデフレ時代の閉塞感を反映して か、幸福についての関心が高くなっている。特に、 ブータンの GNH (Gross National Happiness) に注目が集まって以来、より高くなったと言えよ う。GDP などの経済指標に替わりうるような豊 かさ指標については、かつての $\mathrm{NNW}(\mathrm{Net}$ National Welfare)など、日本においてもいくつか 行われてきたが、マクロ指標として認知されたと はいえず、普及はしなかった。近年、幸福度及び others. Multivariate analysis methods (PCA and probit regression) were used for analysis. Major observations are 1) the residents in this area seem to feel relatively happy, 2) Overall happiness is higher in farm households than non-farm households, 3) so is for the satisfaction on quality of life, inter alia, rural life, 4) happiness is higher in producers of rice for feed than other farm households, 5) happiness correlates to household income and own property in non-farm households and 6) Overall happiness is influenced by other three happiness factors, amenity and satisfaction of income.

生活の質(QOL)に関する指標作りはフランスなど で試みられ (J.E.Stiglitz, A. Sen and J.Fitoussi [8])、日本では内閣府社会経済総合研究所など でなされている1)。幸福はヒトの生き方に深く関 与するために、古代ギリシャ以来、哲学や倫理学 を中心に研究成果は非常に多数あるが、社会科学 からのアプローチは新しく、1970 年以降に始まり、 本格的に取り組むようなったのは 1990 年代後半 だとされる（D.Boreck [1]，B.Frey [3]）。幸福 度は主体が感じる幸福の主観的評価に他ならない 
ために、本来、ミクロ指標であるはずだが、社会 科学、特に経済学ではGDP に比類するようなマ クロ指標として扱われ、マクロ的に分析されてき た。よって、地域性を考慮するにしても、都道府 県レベルであり、地方や農村を対象としたものは 殆どみられず2)、分析も行われてこなかった。ま た、農業者あるいは農家を対象とする分析もなさ れてこなかった。

本研究は、これまでの社会科学分野からの幸福 度研究の成果を検討し、農村（具体的には、農村 部の農家及び非農家）を対象として、幸福に関わ る諸項目について検討し、それに基づくアンケー 卜調査を実施、実態の評価と分析を行う。主眼は、 農村、農家は幸福をどのように評価しているのか、 幸福なのか不幸なのか、その要因は何かを探るこ とである。

\section{2. 指標の選択}

日本において社会科学、とりわけ経済学の観点 から幸福度、生活の質（QOL）を研究し、成果を 公刊しているのは、大竹他 [6]、猪口・SHIN [4]、 檑木［7] であり、また、海外の代表的な幸福研 究で日本に紹介されているのはFrey [3] であろ う。いずれも幸福度は主体の主観的評価であると の考えから、主体が行う総合的な評価を幸福度と している。代表的な質問形式は「あなたは、総合 的に見てどの程度、幸せだとおもいますか、非常 に幸福を○点、最も不幸を○点として、評価をし て下さい」と、主観的評価点を段階で付けるもの である。幸福はきわめて主観的な個人評価であっ て、個々の様々な状況に左右されるために客観化 が困難であることは長年の関連研究が示している 通りであり 3)、結局は、このようなダイレクトな 質問に落ち着いているといえよう。国内外におい て幸福度を継続的に調査している国民選好度調査、 世界価值観調查、アジア・バロメーター4)なども 同様の方法を採用している。よって、本研究で採 用する総合的な幸福度の質問形式も同様のものと し、評価段階は、非常に幸福を 5 、最も不幸を 1 とする 5 段階で門ねることにした。

また、生活の質に関して、生活満足度を幸福度 に類似するものとして捉え、その要因等を分析し、
あたかも幸福度と同じ解釈をしている文献も見受 けられる5)。しかしながら、D.Kahneman [5] は、認知心理学、行動経済学より、生活満足度は 経験する自己の幸福計測値とは別物であると批判 し、幸福は自己の目標を考慮するべきと述べてい る。生活水準が高くても、個人的な様々な理由に よって幸福感に結びつかない場合があり、逆のケ 一スも、十分にあり得る。個々の幸福感は多くの 要因から影響を受け、生活満足度（生活水準）と は必ずしも一致しないからである。猪口・SHIN

[4] は、これまでの幸福研究について、哲学を も含んだサーベイをし、哲学的解釈を考慮した上 で、幸福は「楽しさ」、「満足」、「達成感」が主要 な要素になるとしている。

このような研究成果を踏まえ、生活満足度は幸 福度そのものとは別だとするが、生活の質を評価 する上では欠かせない項目である。そこで、主観 的な総合的幸福度の評価に次ぐものとして、幸福 感を形成する要因を、(1)人生を楽しんでいる程度、 (2)人生における達成度の程度、(3)自分が感じてい る総合的な生活水準の程度として、それぞれ、「非 常に当てはまる」から「全く当てはまらない」ま での 5 段階評価とした。

生活満足度の項目選択については、猪口・SHIN ［4]を参考にした。そこでは生活分野を 5 領域 （個人的生活領域、対人的生活領域、物質主義的 生活領域、非物質的生活領域、公的生活領域）に 分け、領域ごとに項目を複数設定し、総項目数は 16 である。但し、対象はアジア各国であり、アン ケート結果もマクロデータとして取り扱っている。 本研究では、一国よりは地域であることを考虑し、 以下の 16 項目を設定した。住居、家族、友人、 健康、仕事、世帯収入、余暇、精神的ゆとり、食 べること、近所、集落 (自治会)、治安、自然環境、 社会福祉、住みやすさ、結びつきである。それぞ れ満足の程度を 5 段階で尋ねている。

その他関連指標としては、幸福度に影響を与え るであろうと思われる指標を検討した。当該地域 に対して好感を持つのは、なんと言っても地域へ の愛着があるからである。地域に対して拘りを持 つことは、幸福度を高めると考えられる。質問項 目としては、他人に紹介できる地域自慢の程度と 
した。また、あるならば、内容について具体的に 記述することとした。農家の幸福感は農業をする ことに対する意識に左右されるであろう。そこで、 農業の意義及び職業としての意識について、収入 源として」、「つらいもの」、「楽しいもの」、「生き がいがあるもの」、「自然と共生するもの」、「教わ るもの小、「情性的なもの小、「生涯働けるもの」の 8 項目を設定し、自分の考えに該当する項目を複 数選択することとした。幸福は個人の主観によっ て判断されることは既に述べた。個人が幸福をど う感じるかは、主体自身の性格にある程度拠って いることも容易に理解される。性格を判断する指 標として、信頼しやすさの程度と危険回避の程度 の質問項目を設定した。

次に、これまでの研究が示しているように、幸 福度に影響を与えるのは、主体を取り巻く環境、 デモグラフィック指標である。本研究では、農家 に関して、(1)世帯収入（兼業を含む)、(2)世带構成 の数、(3)年齢、(4)農家の状況を示寸指標。非農家 に関しては(1)世帯収入、(2)世帯構成の人数、(3)年 齢、(4)住居年数、(5)資産評価を設定した。回答の 仕方は、資産評価のみ 5 段階評価值とし、その他 はそれぞれの状況に応じた区分評価値とした。

\section{3. 調查概要}

農村地域として山形県遊佐町を選択し、農家と 非農家を対象とした 6)。調査日時は 2012 年 10 月 下旬である。農家に関しては、市街地から離れた 7 集落にある全ての農家(73戸)を対象としたが、 調査拒否、不在もあり、53 戸についてアンケート の配布と回収を行うことができた。調査方法は訪 問調查であり、経営概況調査と併せ調査員が閏き 取りを実施した。非農家に関しては、JR 駅前か ら南東方向に位置する市街地を対象にして、4 町 内会 200 戸にアンケートを配布し、郵送による回 収とした。回収できたのは72（回収率 36\%)、う ち有効は 70 であった。よって、農家 53、非農家 70 の計 123 を分析対象データとした。

簡単にデータの概要について示す。先ず、回答 者の男女別では、農家は男が 100\%である。これ は、アンケート調査を農家経営概況調査に併せて 実施し、聞き取りを経営主または世帯主としたた
めである。回答としては偏っていると言わなけれ ばならない。非農家については、男 $53 \%$ 、女 $47 \%$ となっており、ほぼ妥当な比率である。次に、年 齢別では、農家に関しては経営概況調查の方で実 年齢を聞き区分をした。40歳台 $6 \%$ 、50 歳台 $26 \%$ 、 60 歳台 $36 \%$ 、70 歳台 $24 \% 、 80$ 歳以上 $12 \%$ であ る。先と同様に、調查対象者を経営主または世帯 主としたために、高齢者に偏っている。非農家に ついては、年代別の回答とし、20 歳台 $3 \% 、 30$ 歳台 $4 \% 、 50$ 歳台 $22 \% 、 60$ 歳以上 $61 \%$ であった。 非農家も高齢者が多いことが分かるが農村の高齢 化の一端を示しているともいえる。よって、以下 の分析では、男女別の比較は非農家のみを対象と し、年龄別の分析はなるべく避けることにした。

\section{4. 分析}

\section{1）絰合的幸福度及び幸福要因}

表 1 に、「総合的な幸福度」及び幸福の 3 要因 とした「人生を楽しんでいる程度」、「人生を達成 した程度」、「生活水準の満足度」の回答結果をま とめた。全体の平均值及び農家、非農家別の平均 值である。平均值の検定は農家と非農家で行った。 全般に、平均得点は高いように思え、人生を楽し むこと、人生の達成感は高いとする一方で、生活 水準の評価はそれらに比べ低い7)。農家、非農 家別に見た場合、「総合的な幸福度」、人生を楽し んでいる程度」、「人生を達成した程度」では農家 の方が、有意に值が高い。特に、後 2 者において は明らかに差があり、農家の方が、幸福感が高い ことを示している。そのまま読めば、人生の満足 度がより高いと言うことになる。

\section{表1 幸福度指操の平均值}

\begin{tabular}{|c|c|c|c|c|}
\hline & 秥合* & 人生*** & 这成*** & 生活水妙 \\
\hline 全体平均值 & 3.87 & 3.90 & 3.86 & 2.98 \\
\hline 表称（平均值） & 4.00 & 4.13 & 4.00 & 3.04 \\
\hline 非䧿家（平均值） & 3.77 & 3.74 & 3.75 & 2.93 \\
\hline
\end{tabular}

乼: *は10\%、**は5\%、***は1\%の有意水花を示す

次に、表 2 は非農家のみの男女別の平均値を示 している(農家については省略)。男女別では、有 
意な差があるとは言えないが、全ての項目におい て女性の方が、幸福感が高い。この結果は、これ までの多くの研究で、女性の方が幸福感をより感 じているという結果と整合的である。

\section{表 2 幸福度指㮛男女別平均値}

\begin{tabular}{|c|c|c|c|c|}
\hline & 忞合 & 人生 & 䢖成 & 生活水䍌 \\
\hline 男 & 3.74 & 3.62 & 3.73 & 2.89 \\
\hline 女 & 3.90 & 3.90 & 3.77 & 3.00 \\
\hline
\end{tabular}

\section{2）生活水準の諸項目の評価}

表 3 は、生活満足度指標の 16 項目と地域自慢 の質問について、農家、非農家ごとに平均值と標 準偏差を算出したものである。検定は平均値の差 について示している。

農家の方が非農家に比へ、全ての項目において 満足度が高く、生活全般に渡り、農家の方が満足 していることが窥える。また、有意差がある項目 のうち、「近所」、「集落」、「住む」、「自慢」は市街 地よりは周辺の農村らしい住環境の方をより満足 していることを、「友人」、「仕事」、「余暇」、「精神」、 「食べ物」はどちらかというと農業という職業に よってより特徴付けられる满足度と考えられる。

3）農家属性、非農家属性と幸福度の関係

経営概況・意向に関する調査結果と幸福度と の関係を検討する。幸福度が所得や労働の状況に 関連することは知られている。よって、稼得収入
等を通じて幸福度に関係すると予想されたが、農 家の専兼別、経営規模別、農家収入との関連性は 見られなかった。さらに、農家の属性として表 4 に示している項目について、当該農家であるか無 いかで、幸福度の 4 指標の評価に差があるかどう かを検定したものである。遊佐町は生活クラブ生 協、平田牧場と組み、飼料用米プロジェクトを推 進しているのは周知の通りである。飼料用米に取 り組んでいる農家のみ、幸福度が高いことを示し ているが、その要因は不明である。生きがいとか 積極性が影響しているのかもしれない。後継者が あり、積極的に生活クラブ生協と取り組み意向を 示している農業者は人生の達成感が高い傾向があ る。

次に、非農家の属性と幸福度関連指標との関係 をみよう。幸福度に何が影響しているのか、因果 関係を事前に判断することは難しい。よって、こ こでは、属性（評価指標）と幸福度の 4 つの指標 との相関関倸をみるにとどまる。順位相関係数を 算出した結果を表 5 に示した。収入が高く、資産 の自己評価が高く、地域で自慢できるものがある と感じるほど、幸福度も人生の達成度も生活水準 の満足度も高い評価となっている。また、資産評 価のみ人生の達成感と関連している。単純化して 言えば、資産を持ち、収入があり、地域に愛着が あれば幸福になると言えるかもしれない。

\section{表3 生活满足度の平均値}

\begin{tabular}{|c|c|c|c|c|c|c|c|c|c|c|}
\hline & & 住居 & 家矢 & 友人** & 触康 & 仕事** & 収入 & 余暇** & 精神** & 食べ物** \\
\hline \multirow[t]{2}{*}{ 農家 } & 平均 & 3.58 & 3.72 & 3.75 & 3.28 & 3.51 & 3.17 & 3.53 & 3.45 & 3.83 \\
\hline & 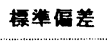 & 0.86 & 0.89 & 0.83 & 0.89 & 0.80 & 0.83 & 0.82 & 0.87 & 0.88 \\
\hline \multirow[t]{2}{*}{ 非農家 } & 平均 & 3.42 & 3.49 & 3.43 & 3.11 & 3.14 & 2.99 & 3.20 & 3.06 & 3.49 \\
\hline & 模䇲回差 & 0.88 & 0.86 & 0.67 & 0.83 & 0.73 & 0.77 & 0.69 & 0.79 & 0.79 \\
\hline
\end{tabular}

\begin{tabular}{cccccccc}
\hline 近所*** & 集落**** & 治安 & 自然 & 福祉 & 住む** & 䊅びつき 自量*** \\
\hline 3.69 & 3.50 & 3.67 & 4.04 & 3.29 & 3.79 & 3.38 & 3.76 \\
0.73 & 0.74 & 0.79 & 0.84 & 0.70 & 0.87 & 0.66 & 0.90 \\
\hline 3.07 & 3.08 & 3.56 & 3.90 & 3.10 & 3.39 & 3.03 & 2.51 \\
0.64 & 0.44 & 0.67 & 0.74 & 0.68 & 0.87 & 0.51 & 0.80 \\
\hline
\end{tabular}

註: *は10\%,**は5\%,***は1\%の有意水準を示す 


\section{表 4 慒家屈性と幸福度（差の挨定結果）}

\begin{tabular}{ccccc}
\hline & 総合 & 人生 & 達成 & 生活水準 \\
\hline エコファーマー & - & - & - & - \\
認定農菜者 & - & - & - & - \\
共同開発米生産者 & - & - & - & - \\
眗料用米生産者 & $\Delta$ & $*$ & - & $* *$ \\
後継者有り & - & - & $\Delta$ & - \\
拡大意向 & - & - & - & - \\
捿極的取組意向 & - & - & $*$ & - \\
\hline
\end{tabular}

註: $\Delta$ は15\%、“は10\%、**は5\%の有意水準を示す

\section{表5 非䘫家風性之幸福度（順位相関係数）}

\begin{tabular}{ccccc}
\hline & 粉合 & 人生 & 達成 & 生活水準 \\
\hline 収入 & $0.401^{* *}$ & $0.374^{* *}$ & 0.257 & $0.467^{* *}$ \\
資産 & $0.367^{* *}$ & $0.459^{* *}$ & $0.370^{* *}$ & $0.425^{* *}$ \\
自慢 & $0.314^{*}$ & $0.455^{* *}$ & 0.241 & $0.245^{*}$ \\
\hline
\end{tabular}

註:*は1\%(両僋)、**は1\%(片側)の有意水準を示す

\section{5。幸福度への影響要因}

これまでの幸福度に関する経済学からのアプロ 一チでは、幸福度に影響を与える様々なデモグラ フィック要因について検討している。幸福の決定 要因の解明を目的としているからである。そこで は、例外なく、方法として、幸福度を被説明変数 とする回帰分析が行われており、幸福度が 2 で述 ベたような順序データなので、順序プロビット法 が採用されている。本研究においても、同様の分 析手法を用いる。

幸福感に影響を与えるデモグラフイックな要因 が何であるかを先験的に判断することは難しい。 はじめにで述べたように、これまでの研究よりあ る程度推測がつくものの、それはマクロの立場か らの判断である。そこで、以下のような分析手順 を経た。先ず、プロビット法ではなく、通常の OLSのステップワイズ法で説明変数を選択した ${ }^{8)}$ 。 次に、選択された説明変数を用いて、順序プロビ ツト法を適用した。

投入する説明変数は、幸福要因指標、生活満足 度の指標、デモグラフィック指標及び性格指標で ある。但し、幸福要因に関する 3 つ指標、「人生 を楽しんでいる程度」、人生を達成した程度」、生 活水準の満足度」は、相互に相関関係を持ってお り、そのままでは多重共線性の問題が発生するた
めに、主成分分析によって合成変量を作成した。 表 6 に示したように寄与率、因子負荷量の大きさ より第 1 主成分を 3 変数の合成変量とすることが できる。分析対象は全サンプルであるが、欠值が あるケースを除外したために、サンプル数は 114 である。

計測結果は、表 7 に示した通りである。ステッ プワイズ法による変数選択を経ているので、有意 な変数のみである。これまでの研究に比べ、幸福 度に与える要因の数は少ない。これは、サンプル 数の少なさ、農村という比較的均一な地域を対象 としていることから生じているのかもしれない。

統合化された幸福要因は幸福度に強い影響を与 えており、幸福指標を作成する際に検討したこと が例証されている。その他は、住みやすさの評価 と収入の評価であり、いずれも生活満足度の主観 的評価值である。住むという総合的な住居環境と 所得に関連する収入への評価が幸福度に影響を与 えていることが示され、幸福を形成する社会・経 済的な要因としては妥当だと判断される。

\section{表6 幸福要因の主成分分析}

\begin{tabular}{cc}
\hline & $\begin{array}{c}\text { 主成分 } 1 の \\
\text { 因子負荷量 }\end{array}$ \\
\hline 人生 & .722 \\
達成 & .835 \\
生活水準 & .741 \\
\hline 寄与率 $(\%)$ & 58.96 \\
\hline
\end{tabular}

表7 幸福度の䝑带分析(順序プロビット法)の推定䊅果

\begin{tabular}{|c|c|c|c|c|c|}
\hline & & 推定値 & 睤準誤差 & Wald & \\
\hline \multirow[t]{6}{*}{ 変数 } & 幸福要因 & 1.282 & .335 & 14.647 & $* * *$ \\
\hline & 住みやすさ評価 & 1.267 & .302 & 17.578 & **** \\
\hline & 収入評価 & .707 & .372 & 3.600 & ** \\
\hline & [cut point $=1]$ & 2.002 & 1.211 & 2.734 & $*$ \\
\hline & [cut point= 2] & 7.688 & 1.444 & 28.356 & $* * *$ \\
\hline & [cut point $=3$ ] & 10.642 & 1.709 & 38.797 & $* * *$ \\
\hline
\end{tabular}

註1)McFaddenの疑似R2: .374

註2)*は10\%、**は $5 \%, * * *$ は1\%の有意水準を示す

註3)WaldはWald統計量を示す

\section{6. おわりに}

本研究においては、これまで、殆ど分析をされ てこなかった農村を対象とした幸福度について、 指標作成の検討をした後、アンケート調査を実施、 
その結果をもとに分析を行ってきた。得られた結 果は以下の通りである。

第 1 に、分析対象農村の総合的な幸福度は比較 的高いと思われる。総合的な幸福度及び幸福を成 す 3 つの要因は、農家の方が非農家よりも高い。

第 2 に、生活満足度についても、全般的に農家 の方が非農家より満足度が高い。特に、農村部特 有の近隣関係や農業を営むといったことについて 顕著である。

第 3 に、農家に関し、属性（経営規模、専・兼 別など）及び世帯収入は幸福度に影響しないが、 飼料用米作付け農家は幸福感が強い。しかし、そ の要因については不明である。

第 4 に、非農家に関し、幸福度と世帯収入、自 己資産評価との間に関係がある。

第 5 に、総合的な幸福度に影響するのは、幸福 構成要因及び住みや寸さと収入であり、暮らして いく上で基本的な事柄である。

第 6 に、地域が持つ資源の評価（自慢できるか どうか）は幸福度に関係している。

以上の本研究の分析結果は暫定的である。既に 述べたように、農村の高齢化が進んでいるとはい え、高㱓者に評価が偏っているからである。また、 分析結果が農村全般的に特徴的なことなのか、そ れとも分析対象地域特有の状況を反映しているの かの判断は、サンプル数だけでなく、他地域を含 めたさらに多くのデータを集め検討する必要があ る。

註

1）内閣府、幸福に関する研究会： http://www5.cao.go.jp/keizai2/koufukudo/koufukudo. html

2）大竹他 [6] では、職業別で農林水産業はあるが、 サンプル数は少ない。檑木 [7] も同様である。地方と は言えないが、東京都荒川区の GAH の取組がある。

3) D. Bok [1]、B. Frey [3]、猪口・SHIN [4] にサ 一ベイと考察がある。

4）以下の HP を参照にされたい。

http://www5.cao.go.jp/seikatsu/senkoudo/senkoudo.

html

http://www.worldvaluessurvey.org/ https://www.asiabarometer.org/ja/profile

5) D. Bok [1],B. Frey [3]。

6）遊佐町の概要：人口 15480 人、世帯数 4608 、高齢 化率 $32.8 \%$ 、農業就業者率 $16.8 \%$

7) 直接的には比較できないが、国民生活選好度調査(内 閣府：2011）では、個人平均 6.4（11 段階評価）とな っている。

8）計測には、SPSS Statistics 19 を用いた。

引用・参考文献

[1] Derek Bok,"The Politics of Happiness" Prinston University Press,2010、(土屋直樹他訳『幸福の研究』 東洋経済新報社、2011)

[2] Carol Graham,"HAPPINESS around the world"2012,OXFORD

[3] Bruno S. Frey, "Happiness A revolution in Economics" Massachusetts University Press, 2008、 （白石小百合訳『幸福度をはかる経済学』NTT 出版、 2013)

[4]猪口孝・Doh Chell SHIN 編『東アジアのクオリテ ィ・オブ・ライフ』、東洋書林、2011

[5] Daniel Kahneman, “Thinking Fast and Slow"2011、 （村井章子訳『ファスト\&スロー』早川書房、2012）

[6]大竹文雄・白石小百合・筒井義郎編著『日本の幸福 ·度』、日本評論社、2010

[7]檑木俊詔『「幸せ」の経済学』岩波書店、2013 [8]J.E.Stiglitz,A. Sen and J.Fitoussi,"Mismeasuring Our Lives" The New Press 2010、（福島清彦訳『暮ら しの質を測る』金融財政事情研究会、2011)

[2014年 4 月 24 日受理] 